\title{
Impact of early infestation with the salmon louse Lepeophtheirus salmonis on the subsequent survival of outwardly migrating Atlantic salmon smolts from a number of rivers on Ireland's south and west coasts
}

D. Jackson*, D. Cotter, N. ÓMaoiléidigh, P. O’Donohoe, J. White, F. Kane, S. Kelly, T. McDermott, S. McEvoy A. Drumm \& A. Cullen.

*Corresponding author; Marine Institute, Rinville, Oranmore, County Galway, Ireland. (dave.jackson@marine.ie; Phone +353 91387200 Fax +353 91 387201)

\begin{abstract}
The potential impact of sea lice infestation on outwardly migrating Atlantic salmon smolts has been investigated by treating populations of ranched salmon, prior to release, with a prophylactic sea lice treatment conferring protection from sea lice infestation, for up to 9 weeks. Established populations of ranched Atlantic salmon with well described rates of return were chosen to investigate the potential contribution of early infestation with the salmon louse, Lepeophtheirus salmonis to mortality in Atlantic salmon. Results of five releases from four locations are presented and compared with a time series of releases from the Lough Furnace in Newport, County Mayo. The results of this study would suggest that infestation of outwardly migrating salmon smolts with the salmon louse (L. salmonis) was a minor component of the overall marine mortality in the stocks studied.
\end{abstract}

Key Words: marine survival, sea lice, Atlantic salmon.

\section{Introduction}

Significant declines in marine survival of Atlantic salmon have been recorded in Ireland (Salmon Management Task Force Report (Anon., 1996); Ó Maoilédigh et al, 2004; Jackson et al, 2011). The reasons for the reduced marine survival remains unclear and speculation has ranged from global warming effects (Friedland et al, 2005) to habitat changes and sea lice infestation (Finstad et al, 2007).

A long term study of lice infestations in outward migrating salmon smolts has been carried out to measure the impact of early infestation of outward migrating salmon smolts with the salmon louse, Lepeophtheirus salmonis Kroyer in established ranched strains. "Ranched" salmon stocks are hatchery reared salmon deliberately released into the wild as smolts with the intention of harvesting all of the returning adults at or near the point of release. The study, based at the Marine Institute research facility in Burrishoole, Newport, County Mayo, has been running for ten years. Results, recently presented (Jackson et al, 2011) show that in the Burrishoole ranched stock over the study period, infestation of outwardly migrating salmon smolts with the salmon louse (L. salmonis) is not a major contributory factor to marine mortality. In order to investigate if these findings held true at other locations and for other stocks a series of five experimental releases at four locations were undertaken, two in 2001 and three in 2006. The results of these experiments are presented here and examined in the context of the results of the Burrishoole time series data (Jackson et al, 2011). 


\section{Materials and Methods}

\section{Experimental Design}

The experimental design followed was similar to that employed in the Burrishoole time series study (Jackson et al, 2011). By treating experimental batches of tagged fish with a prophylactic dose of SLICE ${ }^{\mathrm{TM}}$, a commercial sea lice therapeutant, prior to release, the fish can be protected from infestation with the salmon louse for up to nine weeks. The active ingredient in $\mathrm{SLICE}^{\mathrm{TM}}$ is emamectin benzoate. It is an animal medicine licensed for use in Ireland as a treatment for sea lice infestation in salmon. Treated fish are protected from sea lice infestation in their early weeks in the sea and therefore can be expected to be free of any adverse impacts on their survival related to early lice infestation. As salmon smolts are known to migrate quickly out of the bays and into the open sea treated smolts will have moved well offshore before the protective effects of the SLICE ${ }^{\mathrm{TM}}$ treatment have worn off. Studies at Burrishoole have shown that salmon ranched smolts have moved into coastal waters within 48 hours (Moore et al, 2008). Studies by Shelton et al, 1997 and Dadswell et al, 2010 have shown that smolts from the study area have travelled a distance of over 700 kilometres in seven weeks and are in an area north of Scotland and west of Norway. By comparing their survival and return rates with control fish, which have not been treated with the therapeutant and do not enjoy this protection it is possible to differentiate any additional mortality associated with lice infestation in the first six to eight weeks post migration.

\section{Fish Stocks and Release Groups}

The stocks used in the study were ranched strains with a history of successful release and return over a number of years in the rivers under study. In each of the rivers a ranched stock derived from the wild stock native to the river was used. These stocks are named after the river or fishery of origin (Table 1). In addition a second stock of Burrishoole origin which was being ranched at that time in the Bundorracha river was used in an experimental release in 2001. In each release experimental groups of smolts were split into two approximately equal groups, one treated, and one control. The treated groups were administered SLICE ${ }^{\mathrm{TM}}$ as an in feed preparation at the rate of $50 \mathrm{ug} / \mathrm{kg} / \mathrm{day}$ for seven days. Treatment was completed approximately seven days before the release date of the smolts. Control groups were fed either with food mixed with a placebo or, in certain years, with untreated food after the method of Jackson et al (2011). Samples of treated food were retained and analysed to ensure appropriate inclusion rates and samples of both treated and control fish was taken for flesh analysis. Fish samples were taken two days post feeding to ensure the guts were voided of medicated feed. Flesh analysis for emamectin benzoate was carried out by accredited laboratories to ensure a therapeutic dose was present in the treated groups prior to release. Details of release groups, release locations and release dates are given in Table1.

\section{Tagging}

Experimental batches of fish were all tagged with coded wire tags. Pre-smolts were microtagged according to the methods of Browne (1982). Each magnetised microtag had a specific code which identified the release group and stock of the fish. A $1 \mathrm{~mm}$ 
long magnetised tag, etched with a specific batch code was injected into the nose cartilage of the juvenile fish. The code identifies the origin and release circumstances of any fish subsequently recaptured. All fish were anaesthetised when tagged. The adipose fin was removed to facilitate the identification of these fish in the recovery programme. A quality control check was made on the tagged fish to ensure that the tag has been correctly magnetised. Tagging mortality and tag loss were also estimated and subsequent analyses were based on the numbers of fish migrating rather than the number of fish tagged.

\section{Tag Recovery and Data Analysis}

Information on capture location and return data of the experimental groups was gathered as part of an ongoing Irish national coded wire tag recovery programme (Browne et al, 1994; Ó Maoiléidigh et al, 2004). Catches from coastal commercial fisheries (drift nets, draft nets, etc.) were monitored at 15 major salmon landing ports in Ireland. These fisheries operate between May and July inclusive and catches were scanned consistently during this period. Over $50 \%$ of the catch landed in Ireland is sampled for tags each year. The number of tagged salmon taken in these fisheries (raised data) was estimated by multiplying the actual number of tagged salmon in each area by the ratio of the total declared salmon landings in these areas to the sample size examined. An adjustment for non-catch fishing mortality due to losses from nets and non-reporting of catches was also applied.

A sign test was calculated on the observed returns of treated and non-treated salmon over the entire test period to determine if treatment improved potential of salmon returning. Two way contingency tables were used to calculate expected returns for comparison against observed returns for each yearly pair of treatment and control batches using the Chi-squared test.

\section{Results}

Percentage survival for the each experimental release is shown in Figure 1. Percentage survival rates for all groups are outlined in Table 2 together with the results of Chi-squared tests.

Chi-squared tests of independence showed significant differences in treated and nontreated returning and non-returning rates in two of five instances. In the 2001 release of Burrishoole stock in the Bundorracha, the result was highly significant $\left(X^{2}=30.035\right.$ $p<0.001)$ and in the 2006 release from the river Erne the numbers returning in the treated group were significantly higher than the control group $\left(X^{2}=13.675 p<0.001\right)$.

A sign test was calculated on observed returns of treated and non-treated salmon $(n=5)$. In three instances a greater proportion of treated than non-treated salmon returned, in two instances a greater proportion of non-treated salmon returned (Table 3 ). This result was not significant at $p<0.05$. 


\section{Discussion}

Of the five experimental releases at four locations only two releases resulted in a significantly higher return of the treated group. One of two experimental releases from the Bundorracha River in 2001, the Burrishoole stock, showed a significantly higher survival in the treated group while the native Delphi stock released on the same date showed no significant difference between the treated and control groups. The second experimental release to show a significant difference was the River Erne in 2006. At the other three locations experimental releases resulted in no significant difference between the returns in the treated and untreated group. Taken together with the sign test result (not significant at $p<0.05$ ) these results do not indicate a consistent or major negative impact of early infestation with salmon lice on outwardly migrating salmon smolts from these rivers. Because of the variability in results obtained, both between locations and within one location, in separate releases on the same date, a time series of data from each of the study locations would be required to allow for definitive conclusions to be reached.

When the results of this study are examined in the context of the results of the Burrishoole time series (Figure 2) it can be seen that out of a total of fifteen releases at five locations, twelve are positive, showing a higher rate of return in the treated groups. This result is significant (sign test, $p<0.05$ ) and supports the view that infestation of outwardly migrating salmon smolts with salmon lice has a negative impact on fitness and can contribute to increased marine mortality. However the results of this study and the Burrishoole time series would also point to infestation of outwardly migrating salmon smolts with the salmon louse (L. salmonis) as generally being a minor component of the overall marine mortality in the stocks studied.

When viewed together the percentage return rates for the release groups in this study and in the Burrishoole time series show that different stocks have quite different return rates in their native rivers. Because of the significant decline in return rates over the study period (Jackson et al, 2011) comparisons may only safely be drawn between groups released in the same year. Thus marine survival in 2006 release groups varies from more that $4 \%$ in Burrishoole, on the west coast, to less than $0.2 \%$ in the River Lee, on Ireland's south coast. It is also of interest that Burrishoole stocks ranched from the Bundorracha river in 2001 had a much higher rate of return than either Burruishule stocks ranched from their native river in the same year or the Delphi stocks ranched from the Bundorracha in 2001. These differences will relate to several factors such as stock origin, fish rearing conditions, timing of release and oceanic conditions during the period from smolt migration to adult return.

\section{Conclusions}

The results when examined in conjunction with those from the Burrishoole time series point to infestation of outwardly migrating salmon smolts with the salmon louse $(L$. salmonis) as generally being a minor component of overall marine mortality in the stocks studied. However, analysis of a time series of data from the locations studied similar to that available for the Burrishoole stock (Jackson et al, 2011) would allow a more definitive conclusion to be reached or for observations to be extrapolated to other rivers and stocks. 


\section{References}

Anon., 1996. Making a new beginning in salmon management. Report of the Salmon Management Task Force. Government Publications, Molesworth street, Dublin. 68pp.

Browne, J., 1982. First results from a new method of tagging salmon - the coded wire tag. Fishery Leaflet, Department of Fisheries and Forestry, Dublin, 114. 10pp.

Dadswell, M.J., Spares, A.D., Reader, J.M., Stokesbury, M.J.W., 2010. The North Atlantic subpolar gyre and the marine migration of Atlantic salmon Salmo salar: the "Merry-Go-Round" hypothesis. J. Fish. Biol. 77(3), 435-467.

Finstad, B., Kroglund, F., Strand, R., Stefansson, S.O., Bjorn, P.A. , Rosseland, B.O. , Nilsen, T.O., Salbu, B. , 2007. salmon lice or suboptimal water quality - Reasons for reduced postsmolt survival?

Aquaculture 273, 374-383.

Friedland, K.D., Chaput, G., MacLean, J., 2005. The emerging role of climate in postsmolt growth of Atlantic salmon. ICES Journal of Marine Science 62, 1334-1349.

Jackson, D., Cotter, D., Ó Maoileidigh, N., O’Donohoe, P., White, J., Kane, F., Kelly, S., McDermott, T., McEvoy, S., Drumm, A., Cullen, A., Rogan, G. , 2011. An evaluation of the impact of early infestation with the salmon louse Lepeoptheirus salmonis on the subsequent survival of outwardly migrating Atlantic salmon smolts. Aquaculture, doi:10.1016/j.aquaculture.2011.03.029.

Moore, A., Cotter, D., Quayle, V., Rogan, G., Poole, R., Lower, N., Privitera, L., 2008. The impact of a pesticide on the physiology and behaviour of hatchery-reared Atlantic salmon, Salmo salar, smolts during the transition from fresh water to the marine environment. Fisheries Management and Ecology 15, 385-392.

Ó Maoiléidigh, N., McGinnity, P., Prévost,E., Potter, E.C.E. , Gargan,P., Crozier, W.W. , Mills, P., Roche, W., 2004. Application of pre-fishery abundance modeling and Bayesian hierarchical stock and recruitment analysis to the provision of precautionary catch advice for Irish salmon (Salmo salar L.) fisheries. ICES Journal of Marine Science 61, 1370-1378.

Shelton, R.G., Turrell, W.R. , Macdonald, A., McLaren, I.S. , Nicoll, N.T. , 1997. Records of post-smolt Atlantic salmon, Salmo salar L., in the Faroe-Shetland Channel in June 1996. Fisheries Research 31, 159-162. 



\begin{tabular}{|l|l|l|l|l|}
\hline \multicolumn{1}{|c|}{$\begin{array}{c}\text { Location of } \\
\text { Release }\end{array}$} & Stock & $\begin{array}{c}\text { Release } \\
\text { Date }\end{array}$ & Control (n) & Treated (n) \\
\hline Bundorracha River & Delphi/Burrishoole & $02 / 05 / 2001$ & 6385 & 6392 \\
\hline $\begin{array}{l}\text { Bundorracha } \\
\text { River }\end{array}$ & Delphi & $02 / 05 / 2001$ & 6368 & 6395 \\
\hline River Erne & Erne & $04 / 05 / 2006$ & 10357 & 5752 \\
\hline River Lee & Lee & $04 / 04 / 2006$ & 5131 & 5207 \\
\hline Screebe River & Screebe & $28 / 04 / 2006$ & 9618 & 10990 \\
\hline
\end{tabular}

Table1. Details of release dates and numbers for all stocks.

\begin{tabular}{|l|c|c|c|c|c|c|}
\hline \multirow{2}{*}{ Location of Release } & Stock & $\begin{array}{c}\text { Release } \\
\text { Date }\end{array}$ & $\begin{array}{c}\text { Control \% } \\
\text { survival }\end{array}$ & $\begin{array}{c}\text { Treated } \% \\
\text { survival }\end{array}$ & \multicolumn{2}{|c|}{$\begin{array}{c}\text { Chi-squared } \\
\text { Test }\end{array}$} \\
\hline Bundorracha River & Delphi/Burrishoole & $02 / 05 / 2001$ & 15.39 & 19.05 & 30.035 & $\begin{array}{c}\text { Sig } \\
\text { P }<0.001\end{array}$ \\
\hline Bundorracha River & Delphi & $02 / 05 / 2001$ & 13.98 & 13.11 & 2.053 & NS \\
\hline River Erne & Erne & $04 / 05 / 2006$ & 0.66 & 1.22 & 13.675 & Sig. \\
\hline River Lee & Lee & $04 / 04 / 2006$ & 0.19 & 0.19 & 0.001 & NS \\
\hline Screebe River & Screebe & $28 / 04 / 2006$ & 1.26 & 1.43 & 1.121 & NS \\
\hline
\end{tabular}

Table 2. Details of Percentage survival and Chi-squared significance test results. 


\begin{tabular}{|lllll|}
\hline $\begin{array}{l}\text { Based on \% Standardised } \\
\text { returns }\end{array}$ & $\begin{array}{l}\text { Sign } \\
\text { test }\end{array}$ \\
Location & T - C & & & \\
Delphi/Burr 01 & 3.66 & $\mathbf{n}$ & $\mathbf{5}=\mathbf{1 . 0 0 0}$ \\
Delphi 01 & -0.87 & + & $\mathbf{3}$ & \\
Erne06 & 0.56 & - & $\mathbf{2}$ & \\
Lee06 & -0.003 & & No significant difference at & 0.05 \\
Screebe06 & 0.17 & & & \\
& & & & \\
& & & & \\
\end{tabular}

Table 3. Sign Test results for all locations and releases.

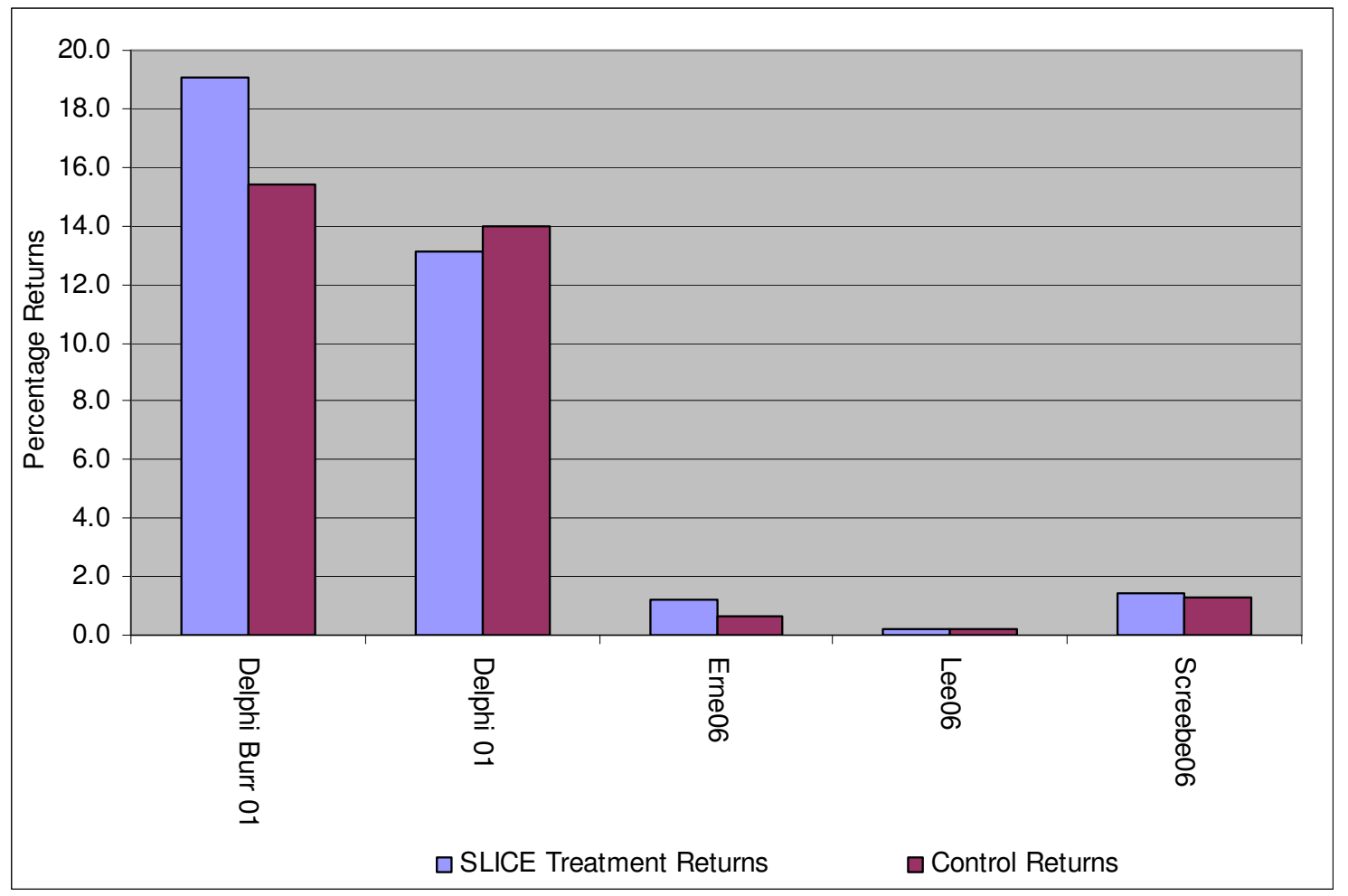

Figure 1. Percentage returns all locations. 


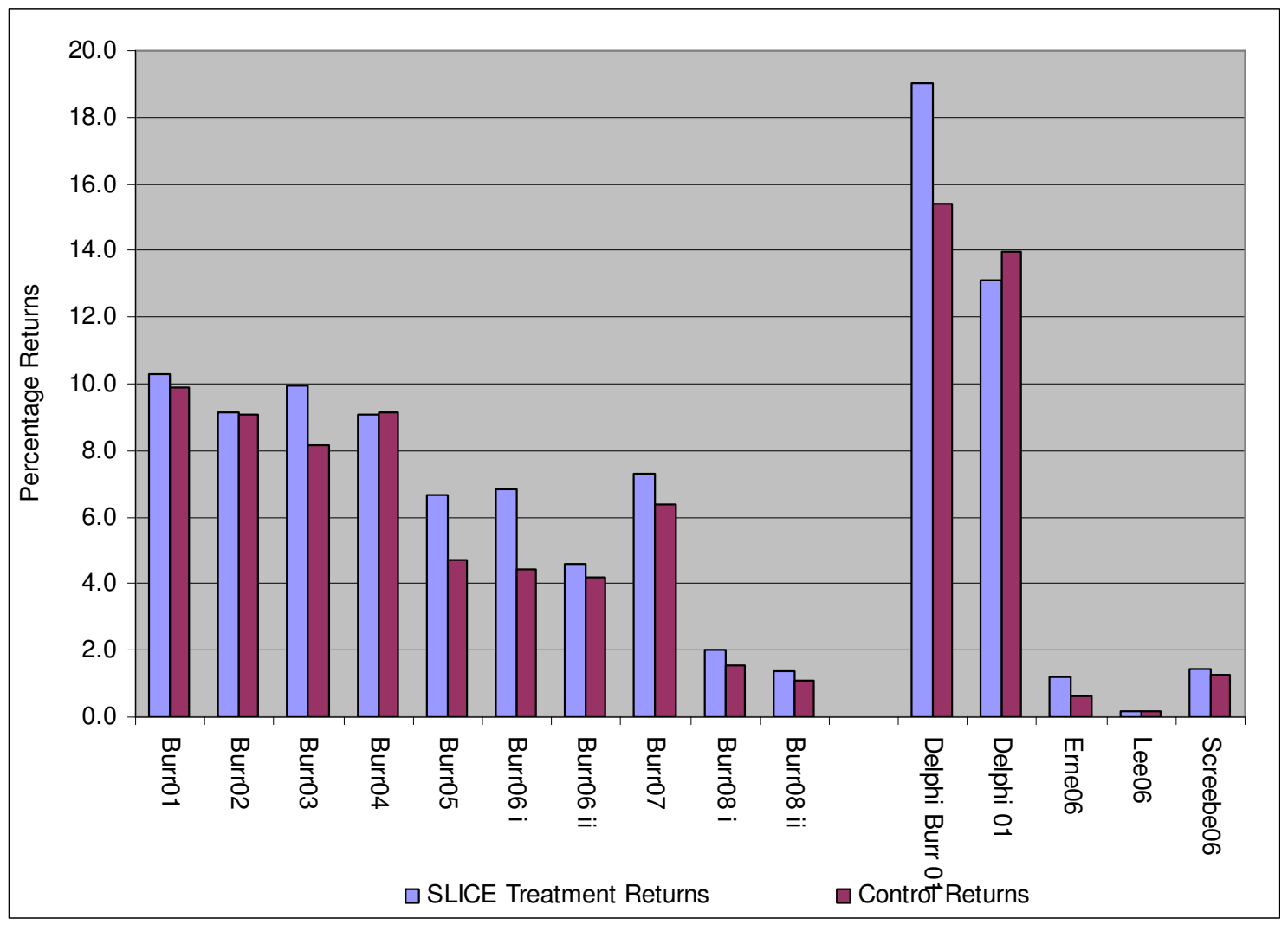

Figure 2. Burrishoole time series (Jackson et al) and results from other rivers. 